\title{
The Effect of Salam Leaf (Syzygium polyanthum [Wight] Walp.) Extract on Inflammation in Rat Model of Acute Coronary Syndrome
}

\author{
Refli Hasan ${ }^{1 *}$, Dharma Lindarto ${ }^{1}$, Gontar Alamsyah Siregar ${ }^{1}$, Zulfikri Mukhtar $^{2}$ \\ ${ }^{1}$ Department of Internal Medicine, Faculty of Medicine, Universitas Sumatera Utara, H. Adam Malik General Hospital, Medan, \\ Indonesia; ${ }^{2}$ Department of Cardiology, Faculty of Medicine, Universitas Sumatera Utara, Medan, Indonesia
}

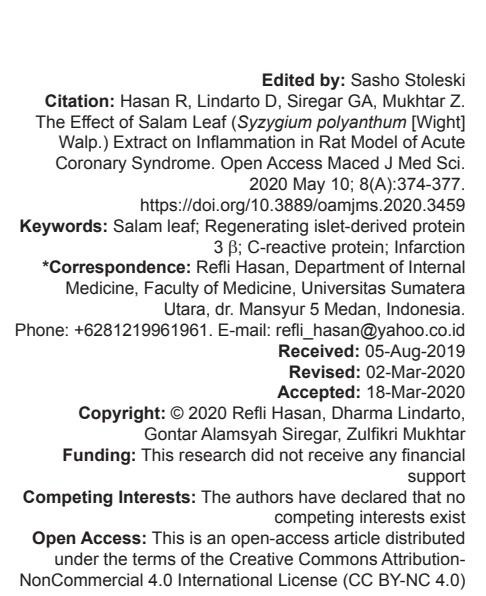

Abstract

AIM: The aim of the study was to determine the effect of Salam leaf extract on regenerating islet-derived protein $3 \beta$ (Reg3 3 ) and C-reactive protein (CRP) in cardiomyocyte of rat model of ACS.

METHODS: Thirty-six male Wistar rats were divided into three groups: Negative control group, positive contro group (ACS-induced group), and treatment group (ACS-induced group with Salam leaf administration). Macroscopic appearance and histopathology examination were done to ensure the occurrence of infarction. Reg3 $\beta$ and CRP levels were measured and compared between the positive control group and treatment group.

RESULTS: There were significantly lower Reg $3 \beta$ and CRP levels in the treatment group than in the positive contro group from day 4 to day 14

CONCLUSION: These data suggest that a Salam leaf extract can improve inflammation by decreasing Reg $3 \beta$ and CRP levels in rat model of ACS.

\section{Introduction}

Cardiovascular disease (CVD) is the leading cause of death in the world. About 17.9 million people died from CVD every year, which account for $31 \%$ of all death globally [1]. In Indonesia, $1.5 \%$ of people suffer from coronary heart disease. Numbers are increasing by age [2]. This high number indicates the need for the development of a new therapeutic strategy to decrease death due to CVD.

The acute coronary syndrome is a condition in which coronary arteries are blocked and decrease oxygen supply to the myocardium. The blockage of these coronary arteries is mostly caused by atherosclerosis [3]. Atherosclerosis itself is chronic inflammation in coronary arteries. Inflammation plays an important role in every stage of atherosclerosis, from development to plaque rupture that can trigger the onset of ACS [4]. The inflammation process can be detected by regenerating islet-derived protein $3 \beta$ (Reg3 $\beta$ ), which is a specific chemokine produced by cardiomyocytes after the occurrence of acute myocardial infarction (AMI). Reg3 $\beta$ expression can provide accurate information about the degree of inflammation of the heart muscle [5], [6].
Besides Reg3 $\beta$, C-reactive protein (CRP) also increases in ACS. CRP is secreted by hepatocyte in response to interleukin (IL)-6, IL-1, and tumor necrosis factor $\alpha$ (TNF- $\alpha$ ) which produced by macrophage [7]. Therefore, CRP examination could detect acute inflammation and severe tissue damage. Lörchner et al. (2018) stated that Reg3 $\beta$ and CRP were increasing in the animal model of ACS. These markers were detected in both cardiomyocytes and serum as early as $24 \mathrm{~h}$ after AMI and remained high few days, afterward [6]. The inflammation process on coronary arteries needs to be controlled to decrease the mortality of ACS.

Local Indonesian plant "daun Salam" or Salam leaf (Syzygium polyanthum (Wight) Walp.) is a medicinal plant from Myrtaceae family. Salam leaf is one of the herbal medicines, which have long been used traditionally in Indonesia to control blood glucose, cholesterol, blood pressure, and also to cure gastritis and diarrhea. Salam leaf contains flavonoids, saponins, tannins, gallocatechin, and atsiri oil, which are thought to have an anti-inflammatory and antioxidant effect [8], [9], [10]. A study in Rattus norvegicus rats, anti-inflammation activity of ethanolic extract of Salam leaf was already occurred on low dose after four hours administration [8]. Based on these evidences, Salam 
leaf could have potential in reducing inflammation process on coronary arteries and thereby reduce mortality in ACS.

We conducted experimental study to demonstrate anti-inflammatory activity of Salam leaf on ACS rat model. Reg3 $\beta$ and CRP levels in cardiomyocytes were chosen as inflammatory marker.

\section{Methods}

This was an experimental study using animals as a research subject. Rats and its intervention were conducted on Animal House, Research Laboratory, Faculty of Medicine, Universitas Sumatera Utara, Medan, Indonesia, while Reg3 $\beta$ and CRP levels were quantified in the Biochemical and Molecular Biology Laboratory of the Medical Faculty of Universitas Brawijaya Malang, Indonesia. This experimental protocol was approved by the Institutional Ethics Committee of Universitas Sumatera Utara, Medan, Indonesia (Reference number 42/TGL/KPEK FK USU-RSUP HAM/2018).

Thirty-six male 10 to 12 -week-old Wistar rats weighing 200-300 g were included in this study. They were housed in stainless steel cages under environmentally controlled conditions. The ambient temperature was $22-25^{\circ} \mathrm{C}$ and the light/dark cycle was $12 / 12 \mathrm{~h}$. The animals had free access to water and standard diet. Rats were divided into three groups: Negative control group in which rats were healthy and did not receive any manipulation, positive control group in which rats were manipulated to have ACS, and treatment group in which rats were manipulated to have ACS and were treated with Salam leaf extraction. Negative control group consisted of four rats. Positive control and treatment group consisted of 16 rats each. To induce ACS, the rats in both positive control and treatment groups were anesthetized with ketamine and thoracotomy was performed. Left anterior descending (LAD) artery was permanently ligated [6]. Rats with ACS were then randomly divided into control and treatment groups. Both groups were divided into four sub-groups each based on termination day (day 1 , day 4 , day 7 , and day 14 ). Rats in the treatment group were administered with an ethanolic extract of Salam leaf in sodium carboxymethyl cellulose (3.6 mg/rats) using an orogastric cannula every day until termination day [11]. Carboxymethyl cellulose was used as viscosity modifier. The extract was prepaired by maceration in the Department of Biological Pharmacy, Faculty of Pharmacy, Universitas Sumatera Utara, Medan, Indonesia. Positive control group receives no additional drug after induction of ACS.

Macroscopic appearance of the heart and histopathology examination on heart tissue was conducted on negative control and positive control group on day 1 after ligation of LAD artery. The macroscopic appearance was documented using stereomicroscope (Leica Microsystems, Singapore). Heart tissue was then examined histopathologically using hematoxylin and eosin (H\&E) staining as mainstay of diagnostic histopathology and Masson's trichrome staining to reveal the extracellular matrix/ collagen deposit [12], [13]. The presence of collagen deposition on heart tissue was documented.

Reg3 $\beta$ and CRP levels were evaluated from a slice of infarcted muscle. For $5 \mathrm{mg}$ piece of tissue, $300 \mu \mathrm{L}$ complete extraction buffer (100 mM Tris, pH 7.4, $150 \mathrm{mM}$ $\mathrm{NaCl}, 1 \mathrm{mM}$ EGTA, $1 \mathrm{mM}$ EDTA. 1\% Triton $\mathrm{X}-100$, and $0.5 \%$ Sodium deoxycholate) was added to the tissue and homogenized. Homogenate was then agitated for 2 hour at $4^{\circ} \mathrm{C}$ and centrifuged for $20 \mathrm{~min}$ at $13,000 \mathrm{rpm}$ at $4^{\circ} \mathrm{C}$. The supernatant was transferred to a fresh, chilled tube and stored at $-80^{\circ} \mathrm{C}$. The cell extraction was supplemented with phosphatase, protease inhibitor cocktails, and PMSF to $1 \mathrm{mM}$, immediately before use. After thawing, samples were centrifuged before use at $10,000 \mathrm{rpm}$ for $5 \mathrm{~min}$ at $4^{\circ} \mathrm{C}$ to remove any precipitate. Reg3 $\beta$ and CRP levels were determined using enzyme-linked immunosorbent assay (ELISA) commercial kits supplied by MyBioSource (USA).

All values were expressed as mean \pm SD. Data were analyzed using an independent t-test in SPSS version 22.0 to identify differences between groups.

\section{Results}

\section{Evidence of cardiac infarction by macroscopic appearance and histopathology}

Macroscopic appearance and histopathology were examined on day 1 after successful ligation of LAD artery on the positive control group. Both rats on negative control and positive control were sacrificed to witness evidence of infarction. The macroscopic appearance of the heart showed intact coronary artery and heart muscle on the negative control group, while on a positive control group, there were constrictions on vessel and blanching in the affected area (Figure 1). Histopathology on the blanching area also showed a lesion on H\&E staining and collagen deposition on Masson's trichrome staining in positive control group (Figure 2).

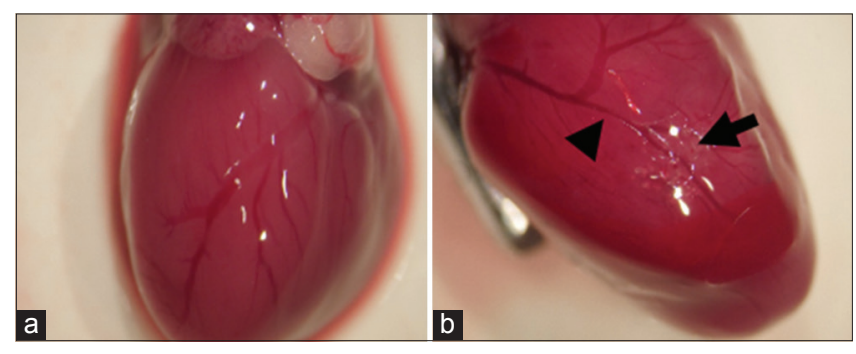

Figure 1: Photomacrography of heart muscle on negative (a) and positive control group (b) at day 1 after ligation of $L A D$ artery on the positive control group. Rats on positive control group showed blanching area on affected muscle (b, pointed by arrow) and constriction on the coronary artery ( $b$, pointed by arrowhead) 


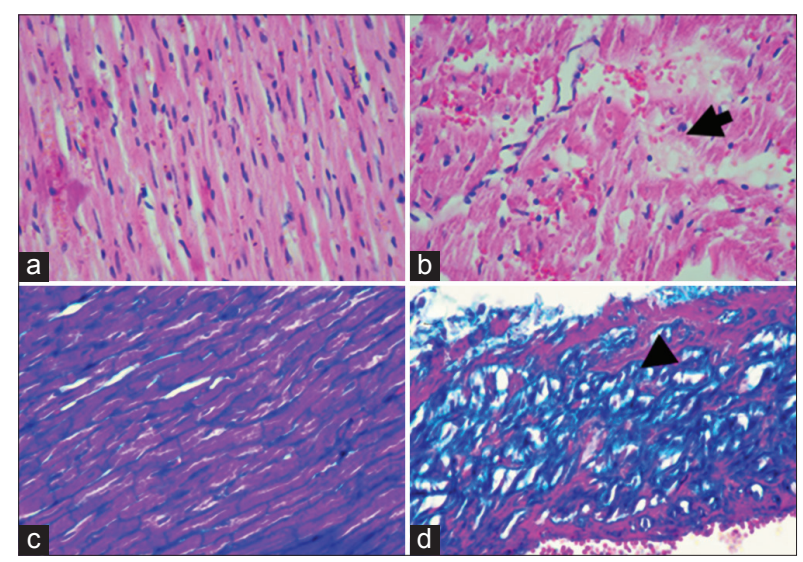

Figure 2: Histopathology of the heart muscle of rats on negative ( $a$ and $c$ ) and positive control group ( $b$ and $d$ ) at day 1 after ligation of left anterior descending artery on the positive control group. Hematoxylin and eosin staining was used both groups ( $a$ and b), so was Masson's trichrome staining ( $c$ and d). Rats on the positive control group showed lesion (b) and escalation of collagen distribution (d) on heart tissue

\section{heart muscle \\ ELISA of Reg3B and CRP on the affected}

Reg3 $\beta$ started to increase on day 1 on positive control group $(2.45 \pm 0.12 \mathrm{ng} / \mathrm{ml})$ compared to negative control group $(0.15 \pm 0.10)$. Reg $3 \beta$ continued to increase when examined on day 4 and day 7 , and reached its highest number on day $14(5.55 \pm 0.52)$. Rising was significant on day 7 and day 14 (Table 1). CRP also showed the same pattern to Reg $3 \beta$. On day 1, CRP level on positive control group was higher $(3.80 \pm 0.15 \mathrm{ng} / \mathrm{ml})$ than negative control group $(0.44 \pm 0.05 \mathrm{ng} / \mathrm{ml})$ that number continued to rise until day 14 (Table 1).

Table 1: Reg3 $\beta$ and CRP of rats on positive control group and treatment group

\begin{tabular}{|c|c|c|c|c|c|c|}
\hline \multirow[t]{2}{*}{ Day } & \multicolumn{3}{|l|}{$\operatorname{Reg} 3 \beta(\mathrm{ng} / \mathrm{ml})$} & \multicolumn{3}{|l|}{ CRP (mg/L) } \\
\hline & $\begin{array}{l}\text { Positive control } \\
\text { group }\end{array}$ & $\begin{array}{l}\text { Treatment } \\
\text { group }\end{array}$ & $\mathrm{p}$ & $\begin{array}{l}\text { Positive } \\
\text { control group }\end{array}$ & $\begin{array}{l}\text { Treatment } \\
\text { group }\end{array}$ & $\mathrm{p}$ \\
\hline 1 & $2.45 \pm 0.12$ & $2.37 \pm 0.39$ & 1.000 & $3.80 \pm 0.15$ & $3.37 \pm 0.25$ & 1.000 \\
\hline 4 & $2.92 \pm 0.35^{\mathrm{a}}$ & $1.44 \pm 0.04^{a_{* *}}$ & 0.002 & $3.95 \pm 0.07^{\mathrm{a}}$ & $1.48 \pm 0.17^{\mathrm{a}}$ & 0.002 \\
\hline 7 & $4.71 \pm 0.34^{\mathrm{b} * *}$ & $0.72 \pm 0.29^{b * \star}$ & 0.001 & $4.57 \pm 0.28^{b_{\star \star}}$ & $0.64 \pm 0.38^{b_{\star \star}}$ & 0.001 \\
\hline 14 & $5.55 \pm 0.52^{\mathrm{c} * \star}$ & $0.25 \pm 0.22^{c}$ & 0.001 & $6.04 \pm 0.45^{\text {c** }}$ & $0.26 \pm 0.10^{c * *}$ & 0.001 \\
\hline
\end{tabular}

After the administration of Salam leaf extract, either Reg $3 \beta$ or CRP, gradually decreased over time. On day 1 , Reg3 $\beta$ level was lower on the treatment group $(2.37 \pm 0.39 \mathrm{ng} / \mathrm{ml})$ compared to the positive control group, but still higher than the negative control group. Reg $3 \beta$ kept decreasing until day $14(0.25 \pm 0.22)$. C-CRP was also decreasing from day $1(3.37 \pm 0.25 \mathrm{ng} / \mathrm{ml})$ to day $14(0.26 \pm 0.10 \mathrm{ng} / \mathrm{ml})$. The differences between the positive control group and treatment group were significant on day 4 onwards (Table 1).

\section{Discussion}

To witness the occurrence of infarction, we compared the macroscopic appearance of the heart muscle, histopathology examination on heart tissue, and inflammatory marker between negative control group and positive control group on day 1. Macroscopically, there was a constriction of the coronary artery and blanching area of the heart muscle. Histopathology of the blanching area also showed an escalation of collagen deposition in the positive control group. Blanching area of the heart muscle and escalation of collagen deposition are the sign of infarction [12] [13] [14]. Moreover Reg3 $\beta$ in positive control group $(2.45 \pm 0.12 \mathrm{ng} / \mathrm{ml})$ was higher than negative control group $(0.15 \pm 0.10 \mathrm{ng} / \mathrm{ml})$. CRP in positive control group $(3.80 \pm 0.15 \mathrm{ng} / \mathrm{ml})$ was also higher than negative control group $(0.44 \pm 0.05 \mathrm{ng} / \mathrm{ml})$. Reg3 $\beta$ is a known inflammation marker produced by cardiomyocyte at the time of infarction to attract macrophages to the sites of injury, while CRP is synthesized and secreted from hepatocyte in response to macrophage's cytokine such as IL-1, IL6, and TNF- $\alpha$. Both markers are useful markers for ACS [6]. Our results ensured that infarct had occurred in the positive control group.

The anti-inflammatory effect of Salam leaf was assessed through a comparison of positive control group and treatment group for 14 days. We found Reg $3 \beta$ and CRP increased from day 1 to day 14 on a positive control group (Table 1), which showed possible, increasing inflammation of heart muscle. In contrast, on the treatment group, Reg3 $\beta$ and CRP were gradually decreased until day 14 . Assuming that Reg $3 \beta$ and CRP levels of negative control at day 1 were the normal value of Reg3 $\beta$ and CRP, Reg3 $\beta$ and CRP levels were decreased close to or even lower than normal levels. This finding indicated inflammation was reduced on the treatment group, showed an anti-inflammatory effect of Salam leaf extract.

Studies showed the various potential of Salam leaf on CVD. Liliwirianis et al. found Salam leaf contained polyphenol compounds such as flavonoid and tannin [15]. Harismah and Chusniatun stated that flavonoid had anti-inflammatory, antiplatelet, anticholesterol, antidiabetes, and antioxidant effect that could be benefit to human [16]. Prahstuti et al. found that quercetin and phloretin were the most types of flavonoids contained in Salam leaf [17]. These flavonoids could inhibit the activity of cyclooxygenase in arachidonic acid metabolism [8]. Quercetin also could decrease total cholesterol and low-density lipoprotein by inhibiting activity and oxidation of HMG CoA reductase and inhibit the secretion of Apo-B 100. Moreover, tannin could inhibit cholesterol absorption in the gut [10]. These evidence indicates that Salam leaf could benefit not only to ACS but also to other CVD.

\section{Conclusion}

Salam leaf extract can improve inflammation by decreasing Reg3 $\beta$ and CRP levels in the rat model 
of ACS. Further studies should be conducted using a flavonoid compound in Salam leaf to establish whether it may represent a novel therapy for ACS. Additional inflammation markers such as IL-1, IL-6, and TNF- $\alpha$ could be used in future studies to provide a better understanding.

\section{Acknowledgments}

The authors acknowledge the assistance of the Department of Biochemistry and Molecular Biology Laboratory, Faculty of Medicine, Universitas Brawijaya Malang, Indonesia.

\section{References}

1. World Health Organization. Cardiovascular Diseases. Geneva: World Health Organization; 2017. Available from: https://www. who.int/news-room/fact-sheets/detail/cardiovascular-diseases(cvds). [Last accessed on 2019 Aug 01].

2. Kementerian Kesehatan Republik Indonesia. Hasil utama Riskesdas 2018. Jakarta: Kementerian Kesehatan Republik Indonesia; 2018. Available from: http://www.depkes.go.id/ resources/download/info-terkini/hasil-riskesdas-2018.pdf. [Last accessed on 2019 Aug 01].

3. Davi G, Carlo P. Platelet Activation and Atherothrombosis. N Engl J Med. 2007;57(14):2482-94.

PMid: 18403776

4. Choi SY, Mintz GS. What have we learned about plaque rupture in acute coronary syndromes? Curr Cardiol Rep. 2010;12(4):338-43. PMid:20425160

5. Lindsey ML, Mouton AJ, Ma Y. Adding Reg3 $\beta$ to the acute coronary syndrome prognostic marker list. Int $\mathrm{J}$ Cardiol. 2018;258:24-5.

PMid:29544938
6. Lörchner $H$, Widera $C$, Hou $Y$, Elsässer $A$, Warnecke $H$, Giannitsis $\mathrm{E}$, et al. Reg $3 \beta$ is associated with cardiac inflammation and provides prognostic information in patients with acute coronary syndrome. Int J Cardiol. 2018;258:7-13.

\section{PMid:29544958}

7. Meier-Ewert HK, Ridker PM, Rifai N, Price N, Dinges DF, Mullington JM. Absence of diurnal variation of C-reactive protein concentrations in healthy human subjects. Clin Chem. 2001;47(3):426-30

PMid: 11238292

8. Agustina R, Indrawati DT, Masruhim MA. Aktifitas ekstrak, daun salam (Eugenia polyantha) sebagai antiinflamasi pada tikus putih (Rattus norvegicus). J Trop Pharm Chem. 2015;3(2):120-3.

9. Novira PP, Febrina E. Tinjauan aktifitas farmakologi ekstrak daun salam (Syzgium polyanthum (Wight) Walp). Farmaka. 2018;16(2):288-97.

10. Sutrisna E, Nuswantoro Y, Said RF. Hypolipidemic of ecthanolic extract of Salam bark (Syzygium polyanthum (Wight) Walp.) from Indonesia (Preclinical study). Drug Invention Today. 2018;10(1):55-8.

11. Syahreza A, Syafriland S, Lindarto D. Comparison of sambiloto (Andrographis paniculata (Burm.f.) Nees) and Salam (Syzygium polyanthum (wight) walp) extract mixture with simvastatin on ferritin concentration in dyslipidemic patients. J Med Plants Stud. 2018;6(6):4-7.

12. Chang J, Nair V, Luk A, Butany J. Pathology of myocardial infarction. Diagn Histopathol. 2013;19(1):7-12.

13. Bloch W, Korkmaz Y. Classical histological staining procedures in cardiovascular research. In: Practical Methods in Cardiovascular Research. Berlin, Heidelberg: Springer; 2005. p. 485-99.

14. De Jong $S$, van Veen TA, de Bakker JM, van Rijen HV Monitoring cardiac fibrosis: A technical challenge. Neth Heart J. 2012;20(1):44-8.

PMid:22161127

15. Liliwirianis N, Musa NL, Zain WZ, Kassim J, Karim SA Preliminary Studies on Phytochemical Screening of Ulam And Fruit From Malaysia. E J Chem. 2011;8(S1):S285-8.

16. Harismah K, dan Chusniatun. Pemanfaatan daun salam (Eugenia polyantha) sebagai obat herbal dan rempah penyedap makanan. Warta LPM. 2016;19(2):110-8.

17. Prahastuti S, Tjahjani S, Hartini E, Kedokteran F. The effect of bay leaf infusion (Syzygium polyanthum (Wight) Walp) to decrease blood total cholesterol level in dyslipidemia model Wistar rats. J Med Planta. 2011;1(4):27-32. 